DOI: 10.14451/2.122.69

\title{
ПУТИ ПОВЫШЕНИЯ ИНВЕСТИЦИОННОГО ПОТЕНЦИАЛА ПЕНЗЕНСКОЙ ОБЛАСТИ НА ОСНОВЕ АНАЛИЗА ЕЕ ИНВЕСТИЦИОННОГО КЛИМАТА
}

\author{
(c) 2018 Козина Елена Вячеславовна \\ кандидат экономических наук, доцент кафедры экономики и управления \\ Пензенский государственный технологический университет \\ 440039, Россия, г. Пенза, проезд Байдукова/улица Гагарина, 1a/11 \\ E-mail: uhelena@list.ru
}

На данном этапе развития рыночной экономики РФ проблема инвестиционной привлекательности социально-экономической региональной системы приобретает все большую актуальность. В статье проанализированы различные аспекты инвестиционной деятельности Пензенской области за период 2013-2017 гг. Выделено ряд направлений, способствующих укреплению инвестиционного потенциала региона. Представлены выводы о причинах снижения объемов инвестиций как в экономику РФ в целом, так и в экономику Пензенской области в частности.

Ключевые слова: инвестиционная привлекательность, инвестиционный климат, инвестиционный потенциал, инвестиции, регион.

Сегодня степень конкурентоспособности любого государственного образования в социально-экономическом отношении определяется не только валовым внутренним продуктом (ВВП), но и непосредственно зависит от способности привлечения российских и зарубежных инвесторов для успешного осуществления инвестиционных проектов по расположению и формированию производительных сил на определенной территории, а так же от степени привлекательности инвестиционного климата данной территории.

Для того, чтобы говорить о стратегии развития инвестиционного потенциала региона, необходимо в первую очередь выяснить сущность данной категории.

Под региональным инвестиционным климатом принято понимать «систему отношений, формирующихся под воздействием широкого круга взаимосвязанных процессов и совокупности условий инвестиционной деятельности политического, социально-психологического, финансово-экономического, законодательного, нормативно-правового, экологического, криминального, ресурсно-сырьевого, производственного, инновационного, трудового, инфраструктурного, потребительского и институционального характера и подразделяющихся на свои макро-, микро- и собственно региональные уровни управления, отражающие как объективные возможности региона к развитию и расширению инвестиционной деятельности, характеризующие его инвестиционный потенциал, так и условия деятельности инвесторов (инвестиционный риск), создающие предпосылки для появления устойчивого побуждения к инвестированию, оказывающего существенное влияние на доходность инвестиций и уровень инвестиционных рисков и определяющего целесообразность и эффективность инвестиций» [3].

Инвестиционная привлекательность региона - это набор определенных факторов, формирующих поступление инвестиционного капитала в регион.

По мнению автора, инвестиционная привлекательность региона состоит из двух основных факторов - это инвестиционный потенциал региона и инвестиционные риски.

Инвестиционный потенциал региона - это набор определенных характеристик региона, таких как природно-естественные, политические, социальные и экономические, посредством которых определяются возможности региона для привлечения инвестиций.

Инвестиционный риск - законодательные условия деятельности инвесторов с точки зрения вероятности потери инвестиций и дохода от них.

Динамичное и эффективное развитие инвестиционной деятельности является необходимым условием стабильного функционирования и развития экономики.

Экономический рост и инвестиционная активность являются взаимообусловленными процессами, поэтому вопросы управления инвестициями играют огромную роль как для эко- 
номики региона и макроэкономики в целом.

Сегодня отечественная экономика имеет большинство необходимых инвестиционных ресурсов. Однако значимого роста инвестиций в реальный сектор экономики мы не наблюдаем.

Вплоть до 2016 года наблюдаем сокращение объема инвестиций в основной капитал и снижение ВВП (табл. 1).

Как показывают данные табл 1., в период с 2013 по 2015 гг. произошло снижение как показателя ВВП, так и инвестиций в основной капитал, однако с 2016 года наметилась противоположная положительная тенденция, а именно рост показателя ВВП в 2016 году по сравнению с 2015 г. на 3,9\%, в 2017 году по сравнению с 2016 г. на 1,9\%, инвестиции в основной капитал увеличились в 2016 году по сравнению с 2015 г. на 9,9\%, в 2017 году по сравнению с 2016 г. на 4,6\%, что свидетельствует об опережающем росте инвестиций по сравнению с ростом ВВП.

Аналогичную ситуацию мы имеем и в ряде регионов России, что говорит о постепенном росте экономики в целом и стабилизации некоторых экономических процессов, в частности.

Оценка инвестиционных процессов в Пензенском регионе показала, что в 2016 году объем инвестиций здесь резко сократился (объем инвестиций за 2016 год по крупным и средним предприятиям составил 1055,9 млн. руб. и составляет 73,0\% к уровню 2015 года).

Однако в 2017 году наблюдается уверенный рост инвестиций в экономику региона.

Так, объем инвестиций в экономику Пензенской области по итогам 2017 года составил 72 с половиной млрд. рублей, что на 7,6\% больше чем в 2016 году.

В 2017 году по уровню инвестиционного потенциала Пензенская область заняла 21 место в Национальном рейтинге состояния инвестиционного климата в субъектах РФ. Инвестиционный рейтинг региона перешел из группы регионов с умеренным уровнем инвестиционного риска и пониженным потенциалом (категория 3B1) в группу с пониженным потенциалом и минимальным инвестиционным риском (категория 3А1).

В 2017 году региональный индекс промышленного производства вырос на 2,6\%, что выше среднего по России на 1,6\%.

Первое место среди регионов Приволжского федерального округа Пензенская область занимает по показателю «Рост промышленного производства», за три последних года рост составил $113,1 \%$.

В табл. 2 представлены показатели, характеризующие инвестиционные процессы в Пензенской области за 2013-2016 гг. [5]

Как видно из данных табл. 2 с 2013 года область ежегодно наращивала инвестиционный потенциал, однако в 2016 году, произошло снижение по всем показателям.

В период с 2013 г. по 2015 год объем инвестиций в основной капитал возрос с 80114,1 млн. руб. до 89042,1 млн. руб. Динамика показателя «индекс физического объема инвестиций в основной капитал» говорит о том, что увеличение происходило не только в фактических, но и в сопоставимых ценах.

Таблица 1. Динамика ВВП и инвестиций в основной капитал России

\begin{tabular}{|l|c|c|c|c|c|}
\hline \multicolumn{1}{|c|}{ Показатель } & 2013 г. & 2014 г. & 2015 г. & 2016 г. & 2017 г. \\
\hline ВВП, в \% к предыдущему году & 101,8 & 100,7 & 95,7 & 99,6 & 101,5 \\
\hline Инвестиции, в \% к предыдущему году & 100,8 & 98,5 & 89,9 & 99,8 & 104,4 \\
\hline
\end{tabular}

Источник. По данным www.gks.ru.

Таблица 2. Показатели, характеризующие инвестиционные процессы в Пензенской области за 2013-2016 гг.

\begin{tabular}{|c|c|c|c|c|}
\hline Показатель & 2013 г. & 2014 г. & 2015 г. & 2016 г. \\
\hline Валовой региональный продукт, млрд. руб. & 270,4 & 295,2 & 336,5 & 360,2 \\
\hline Объем инвестиций в основной капитал, млн. руб. & 82164,1 & 82079,5 & 89042,1 & 65029,8 \\
\hline $\begin{array}{l}\text { Индекс физического объема инвестиций в основной } \\
\text { капитал,\% }\end{array}$ & 114,1 & 98,4 & 101,0 & 68,8 \\
\hline Численность населения (на конец года), тыс. чел. & 1361 & 1356 & 1349 & 1342 \\
\hline $\begin{array}{l}\text { Объем инвестиций в основной капитал на душу } \\
\text { населения, руб./чел. }\end{array}$ & 60210 & 60437 & 65852 & 48345 \\
\hline
\end{tabular}


Однако в 2016 году произошло сокращение инвестиций в основной капитал на $27 \%$ по сравнению с 2015 годом.

Снижение численности населения региона обусловлено как низкой рождаемостью, так и высокой смертностью. По данным Росстата в 2017 году смертность в Пензенской области превысила рождаемость на $57,7 \%$.

В отраслевом разрезе инвестиции в основной капитал Пензенской области в период с 2015 по 2016 год выглядят следующим образом (см. табл. 3) [5, 6].
Анализ инвестиций Пензенской области в основной капитал по чистым видам экономической деятельности в 2015-2016 гг. показывает, что наибольший удельный вес в общем объеме составляют инвестиции, в транспорт и связь; сельское хозяйство, охоту и лесное хозяйство; обрабатывающие производства (рисунок 1).

Поступление иностранных инвестиций в регион, так же является весьма важным, так как одновременно с зарубежными инвестициями в экономику региона вовлекаются инновационные технологии, современные методы управле-

Таблица 3. Инвестиций в основной капитал Пензенской области по видам экономической деятельности в 2015-2016 гг. (млн. руб.)

\begin{tabular}{|l|c|c|}
\hline \multicolumn{1}{|c|}{ Отрасль } & 2015 год & 2016 год \\
\hline Сельское хозяйство, охота и лесное хозяйство & 12015,9 & 7364,4 \\
\hline Рыболовство & - & - \\
\hline Добыча полезных ископаемых & - & - \\
\hline Обрабатывающие производства & 9909,3 & 5445,6 \\
\hline Производство и распределение электроэнергии, газа и воды & 1512,0 & 3096,1 \\
\hline Строительство & 94,4 & 194,5 \\
\hline $\begin{array}{l}\text { Оптовая и розничная торговля; ремонт автотранспортных средств, } \\
\text { мотоциклов, бытовых изделий и предметов личного пользования }\end{array}$ & 1215,7 & 1335,7 \\
\hline Гостиницы и рестораны & 78,4 & 60,3 \\
\hline Транспорт и связь & 26060,6 & 8080,5 \\
\hline Финансовая деятельность & 236,7 & 234,7 \\
\hline Операции с недвижимым имуществом, аренда и предоставление услуг & 4854,8 & 3753,3 \\
\hline $\begin{array}{l}\text { Государственное управление и обеспечение военной безопасности; } \\
\text { социальное страхование }\end{array}$ & 653,4 & 701,1 \\
\hline Образование & 682,9 & 856,5 \\
\hline Здравоохранение и предоставление социальных услуг & 1167,9 & 1118,5 \\
\hline
\end{tabular}

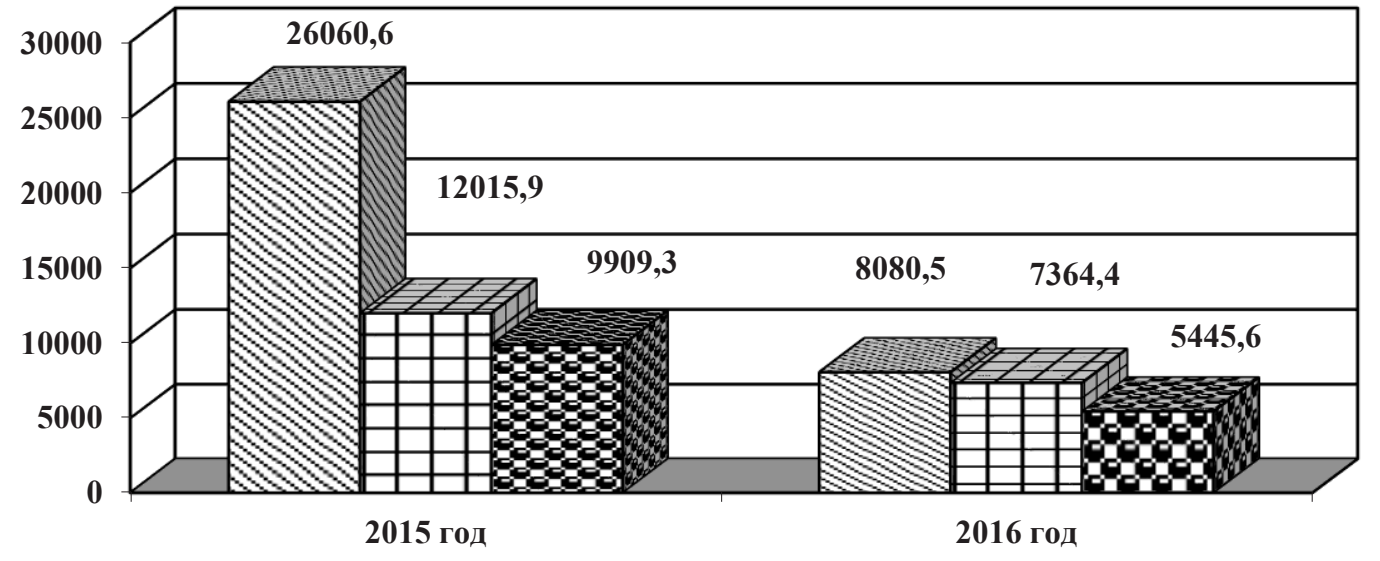

口Транспорт и связь, млн.руб.

口Сельское хозяйство, охота и лесное хозяйство, млн. руб.

ФОбрабатывающие производства, млн. руб.

Puc. 1. Инвестиций в основной капитал по видам экономической деятельности Пензенской области в 2015-2016 гт. 
ния предприятиями, высококвалифицированные специалисты различных уровней.

В целях создания позитивного инвестиционного имиджа и реализации перспективных инвестиционных проектов Пензенской области ежегодно в городе Пензе проводятся Инвестиционные Форумы «Экономика стимулов - peгиональная модель», «Новые источники роста экономики регионов», в которых принимают участие представители российских деловых кругов и бизнеса, иностранных государств [1].

В текущем году в регионе подписано 9 крупных инвестиционных соглашений. Объем инвестиций по данным соглашениям составляет почти 15 млрд. рублей.

Среди наиболее значимых инвестиционных проектов для области следует выделить:

- группа компаний «Русмолко» («Пачелмское хозяйство») проект по строительству молочно-товарного комплекса замкнутого цикла на 5200 дойных коров в Сердобском районе. Объем инвестиций $-5,5$ млрд. руб.;

- агропромышленное предприятие «Восток Агро» проект по строительству животноводческого комплекса на 2250 голов дойного стада и элеваторного комплекса в Кузнецком районе. Объем инвестиций составляет более 4,5 млдр. руб.;

- группа «Черкизово» проект по созданию свиноводческого комплекса на 280 тысяч голов в Пензенском районе;

- компания «Дамате» проект по расширению производства мяса индейки до 155 тысяч тонн в год. Общий объем инвестиций составляет 41 млрд. руб.;

- компания «Хохланд Руссланд» проекта по производству мягких плавленых сыров на площадях «Белинского сыродельного завода». Объем инвестиций около 2 млрд. руб.;

- группа компаний «ФомЛайн проект по производству поролона в городе Кузнецке;

- компания «Лопатинский бекон» проект по строительству свинофермы на 32 тысячи голов в Лопатинском районе. Объем инвестиций 600 млн. руб.

Однако проведенный мониторинг реализации инвестиционных проектов реализуемых в рамках инвестиционных соглашений и протоколов о намерениях, заключенных на инвестиционных форумах Пензенской области, показал, что около $40 \%$ из них либо приостановились, либо не начинались[2].
Анализируя все вышеизложенное можно сказать о наличии ряда причин снижения объёмов инвестиций за анализируемый период как в экономику РФ в целом, так и в экономику Пензенской области.

Одна из самых очевидных - последствия финансово-экономического кризиса и введение экономических санкций против России рядом зарубежных государств.

Низкие показатели, на взгляд автора, имеют тесную взаимосвязь со следующими причинами - это ориентированность экономики и экспорта на добычу углеводородного сырья, которое сильно потеряло в цене, а также отсутствие высокотехнологичных производств либо их слаборазвитость; неразвитая инфраструктура, в том числе транспорт, связь, система телекоммуникаций; отсутствие единой государственной политики в области привлечения инвестиций; коррупция и криминализация отдельных сфер предпринимательской деятельности [2].

Для того чтобы определить способы укрепления инвестиционного потенциала региона необходима реализация комплексных, взаимоувязанных по ресурсам, срокам и этапам преобразований по следующим векторам:

Первый вектор - наращивание человеческого капитала (трудовой потенциал).

Повышение качества жизни населения, увеличение заработной платы, улучшение демографической ситуации, формирование эффективного инструментария конкуренции на региональном рынке труда.

Второй вектор - формирование современной инфраструктуры, которая будет способствовать развитию инновационной деятельности в регионе (бизнес - инкубаторы, технопарки, венчурный фонды, логистические центры и т.п.).

Третий вектор - наращивание конкурентных преимуществ предприятий, посредством, формирование кластеров в инвестиционно- привлекательных отраслях экономики (приборостроение, медицина, лесопереработка, сельское хозяйство), модернизация или диверсификация морально устаревших производств.

Четвертый вектор - дополнительные льготы хозяйственной деятельности в сфере промышленности и в сфере новых технологий (особенно для компаний развивающих и внедряющих новые виды производств, IT-технологий), в сфере переработки сельскохозяйственной продукции. 
Успешная реализация всех вышеперечис- региональном так и на муниципальном уровнях ленных направлений требует тесного и эффек- в интересах достижения намеченных целей интивного взаимодействия, как на федеральном, вестиционного развития региона.

\section{Библиографический список}

1. Дерябина Я. Сравнительный анализ подходов к оценке инвестиционной привлекательности и инвестиционной активности регионов // Инвестиции в России. № 8. 2003. С. 13.

2. Козина E.B. Организационно-методический инструментарий формирования регионального кластера в контексте обеспечения устойчивого развития территорий: диссертация кандидата экономических наук: 08.00.05 / Козина Елена Вячеславовна.- Тамбов, 2012.-156 с.

3. Савинова О.В., Козина Е.В. Формирование стратегии развития инвестиционного потенциала региона // Региональная экономика: теория и практика. 2010, № 30. С. 49-52.

4. Официальный портал Пензенской Области. URL: http: www.penza.ru

5. Федеральная Служба Государственной Статистики. URL: http: www.gks.ru

6. Закон Пензенской обл. от 30.06.2009 № 1753-ЗПО «О Внесении изменений в закон Пензенской области «О стратегии социально-экономического развития Пензенской области на долгосрочную перспективу (до 2021 года)». URL: http://www.regionz.ru/index.php?ds=295144

Поступила в редакцию 31.08.2018 